The Dhaka University Journal of Linguistics: Vol. 2 No.3 February, 2009 Page: 69-90, Published on December 2009 by the Registrar, Dhaka University ISSN-2075-3098

\section{Listening Skill At Tertiary Level: A Reflection}

Md. Minhajul Abedin ${ }^{1}$, Saiful Hassan Khan Majlish ${ }^{2}$, Shorna Akter ${ }^{3}$

1. Lecturer in English, Stamford University Bangladesh

2. Lecturer in English, The People's University of Bangladesh

3. Lecturer in English, Dhaka City College

\section{Abstract}

This study focuses on the real scenario of listening skill of learners at the tertiary level in private universities in our country and through this attempt we have tried to find out the reasons of poor listening skills of the learners. At secondary and higher secondary level, where Communicative Language Teaching (CLT) is in practice, writing and speaking are given maximum importance. Since learners' listening skill is not assessed like other skills, it remains unattended through out their academic career. The scenario of poor listening skill of the learners continues with the same negligence even at the tertiary level. Giving importance to the development of this skill, the study has been done throughout questionnaire survey both from students' and teachers' point of view. The survey result has been analyzed and some suggestions are given regarding the matter.

Key words: Listening Skill, Tertiary level, Private Universities

\section{Introduction}

In our context, CLT is applied at school and college level. Because of some specific reasons, it is found that the application of CLT remains closed within the pages of Syllabus and curriculum. In other words, CLT approach is found in theory format. Students are asked here directly or indirectly to develop their writing and speaking skills. But reading, writing, speaking and listening are integrated skills. A learner cannot be efficient in English language until and unless he/she is equally proficient in all the four skills. But the avoiding tendency to listening skill continues even at the tertiary level. While in secondary and higher secondary level, teachers get less scope to teach all the four skills of English language at class room, at the tertiary level teachers at least get some opportunities to concentrate on this matter as at this level the number of students can be controlled. It is found that $86 \%$ students are of Bengoli medium background (Jahan and Jahan, 2008:162). So, it becomes difficult for the students of private universities, where medium of instruction is English, to cope with any wholly controlled English speaking environment of class room. In order to communicate orally in English, development of listening skill is a must. So, the university authority or those who are concerned with the syllabus/ curriculum designing and teaching English language; should take into account the acuteness of the listening problem or the necessity of developing listening skill seriously to take immediate and effective measure to solve the problem as well.

\section{Purpose of the study}

The goal of the study is to find out the reasons of the listening problem of the students at the tertiary level at private universities. In order to analyze the problem both teachers and students point of view regarding the matter has been taken into account. It tends to find out some effective and necessary solution of this problem, so that both the teachers and the students can be benefited in their objective and product out come regarding listening skill development consecutively. 


\section{Literature Review}

In order to be competent at communication in English language learners have to be skilled in the four skills. While Hymes (1972:159) mentioned 'communicative competence' as the aim of language teaching, Richard and Rodgers (2001:159) have explained the matter as. "The communicative approach in language teaching starts from a theory of language as communication". Chomsky regards language theory in terms of 'homogeneous speech community'. He (1965:3) holds:

Linguistic theory is primarily with an ideal speakerlistener in a completely homogeneous speech community, who knows its language perfectly and is unaffected by such grammatically irrelevant condition as memory limitation, distractions, shifts of attention and interest, and errors (random or characteristic) in applying his knowledge of the language in actual performance.

Chomsky discusses the application of the theory of language in terms of native English speakers' communication and indirectly he mentions the problems of the non-native speakers in the communication in English language. For the communication in real life, the development of the listening skill is very important. In this regard, Rixon (1986: 1) says, "The aim of teaching listening comprehension is (or should be) to help learners of English cope with listening in real life, but there is a large variety of different types of listening". Harmer (1998: 97-98) explains the aim of teaching listening as:

One of the main reasons for getting students to listen to spoken English is to let them hear different varieties and accents - rather than just the voice of their teacher with its own idiosyncrasies. In today's world, they need to be exposed not only to one variety of English ... The second major reason for teaching listening is because it helps students to acquire language subconsciously even if The Dhaka University Journal of Linguistics teachers do not draw attention to its special features... Lastly, just as with reading, students get better at listening the more they do so! Listening is a skill and any help we can give students in performing that skill will help them to be better listener.

\subsection{Listening Process}

Listening is a complex interactive process where listeners actively interpret with what they know and what they are hearing. It can be also explained from schematic point of view which involves the connection between the background knowledge and the knowledge currently they are acquiring. Listening skill plays the role of the connector, in other words it acts as a bridge of learning process. In this connection, Vandergrigt (2002:2) says:

Listening comprehension is ...an interactive interpretive process where listeners use both prior knowledge and linguistic knowledge in understanding message. The degree to which listeners use the one process or the other will depend on their knowledge of the language, familiarity with the topic or the purpose for listening.

Listeners' role is not just to hear. Actually listening involves comprehension. In this respect Wipf (1994: 345-8) has said that listeners should be able to recognize the sound, word meaning and structures and they should have attention to the stress and intonation. Wipf (1994: 345-8) has again added that students should be conscious about the socio-cultural context of the exposed content.

\subsection{Concept of Standard Language}

For the non native speakers the concept of Standard English for spoken should be clear because English language is used in a good many number of countries and therefore obviously there 
is the chance of localized accent of English. In this regard Perera (1994: 80-81) says:

Standard English may be spoken in an accent that does not reveal the speakers' geographical origin - in England such an accent is called Received pronunciation (RP) ... when the National Curriculum stipulates that pupil should be using standard English fulfill statements of attainment in speaking and listening, this does not mean that they are require to change their accents.

\subsection{Poor listening skill- some reasons}

The learners in our country sometimes face difficulties in understanding pronunciation, syntactic, semantic and contextual meaning of listening materials. Anxiety about foreign language plays a vital role in this respect. The pronunciation of the native speakers creates huge problem for the non-native speakers. As a result the non native learners can understand or comprehend neither the content nor the language. In this regard Rixon mentioned some major sources of listening difficulties (1986:38-39):

1. The weak relationship between English sounds and the way they are spelt in the written language.

2. Changes in sounds when they occur in rapid, connected speech.

3. The rhythm patterns of English speech.

4. Different ways of pronouncing the 'same' sound.

1.The weak relationship between sound and spelling

Many learners know English well in its written form, but when it comes to listening to the spoken language this experience is of little help to them...Many learners of English fail to recognize the spoken form of words that they 'know' very well in print or writing.

The Dhaka University Journal of Linguistics
2. Sounds in connected speech

Many learners are accustomed to hearing a very careful, clear pronunciation of word, such as a native speaker might use when talking very emphatically or saying words in isolation. Once words are used in a connected natural utterance, some of their sounds are different to those used in very careful speech; they may become harder for learners to recognize.

3. The rhythm pattern of English speech

By 'rhythm' we mean the pattern and timing of stresses. This holds good for both music and language. In both of these one can distinguish stresses (heavy beats) from unstressed beats. In language, each beat corresponds to a syllable.

Languages are often split into two main categories - those in which the stresses tend to come at roughly equal interval of time (to produce a regular 'tum tum' rhythm), and those in which the rhythm is less regular, with different amounts of time elapsing between the stresses.

4. Different ways of pronouncing the 'same' sound Many teachers assume that students' listening difficulties exactly mirror their difficulties with pronunciation. Fortunately this is not entirely the case. The context usually helps learners distinguish similar-sounding words when they form part of a whole utterance.

\subsection{Teacher's Role}

In CLT approach, teachers are to play the role of a facilitator in the class room. Teachers should encourage the students not to take language as chunk rather to take the entire thing as a whole. In this regard, Rixon has opined that, as the learners want to understand every word from any listening materials, they face problem and they panic for their because of the failure in grasping the meaning of all the words

Good teachers are to apply certain strategies in the class room so that the students can get the maximum benefit by involving

$$
\text { Vol. } 2 \text { No. } 3 \text { February, } 2009
$$


them (the learners) in the task of the class. In order to make the whole listening program fruitful the teachers will apply effective guideline to the learners. Johnson (1994:38-90) says that for the development of confidence among the learners the teachers have to consider some of the more complex issues like, gender and talk, linguistic diversity and variety and learners' special needs. Johnson (1994:38-90) further suggests the teachers that they should not be biased in assessing the students. Identifying the listening problems experienced by the students Johnson sorts out some strategies which were found to be successful (1994:39):

1. pairing pupil with supportive partners;

2. putting pupils into the role of questioner and interviewer;

3. planning for well structured small- group work with clear time limits;

4. asking for appropriate teacher interaction in small group work;

5. tape- recording individual pupils doing their tasks, using a microphone where necessary.

6. providing pupils with a cassette player so that they can record their work orally rather than in writing;

7. reducing extraneous noise and explaining tasks very fully and explicitly;

8. using drama, role play, puppets and play to encourage participatory talk.

Byrnes (1984:317-29) opines for teachers', providing necessary background knowledge for the students. If cognitive psychology is taken into account, then it will be found that listening comprehension is not mere understanding meaning from listening materials. In accordance with the view of The Dhaka University Journal of Linguistics
Vandergrift (2002:2), listening is a process of matching speech with what listeners actually know about the topic.

\subsection{Phases of listening}

Listening is primarily Extensive and Intensive. Vanedegrift (2002:3) says that, in Extensive listening stage students learn more in relax mood and condition than in Intensive listening and the listening materials may be radio program, song, drama, talk show etc. Harmer (2001: 228) says in this regard:

Extensive listening will usually take place out side the class room, in the students' home, car or on personal stereos as they travel from one place to another. The motivational power of such an activity increases dramatically when students make their own choices about what they are going to listen to.

Harmer (2001:228-9) has explained both Intensive and Extensive listening, and in case of Intensive listening, students get exposure to some planned listening materials, and they are supposed to collect and organize information from that extract. Material for Intensive and Extensive listening is different; where Intensive listening materials are carefully and deliberately designed compared to the Extensive listening materials; as Rixon (1986:10) says:

The type of passage used is usually a little different from that used for extensive listening. It contains more concrete information, which may be quite densely packed, and often is not as easy for the students to understand on first hearing. This is because the aim is to give the students a challenge, to allow them to develop listening skills or knowledge of language through the efforts they make, guided by exercise or activities related to the passage.

Anything, which is taught in unstressed condition, is likely to last long in the mind of the students. Relax and easy way of teaching and learning process is essential to have good feedback from the learners. Dudly, Burt and Krashan (in

Vol. 2 No.3 February, 2009 
Tomloson, 1998: 8) have said in favor of learning in anxiety free condition:

Research has shown...the effect of various forms of anxiety on acquisition: the less anxious the learner, the better language acquisition proceeds. Similarly, relax and comfortable students apparently can learn more in shorter period of time.

It can be said that if students are properly motivated than the learners will gain quick listening skill through extensive listening materials where students select the appropriate reading materials for them.

Richard (1990:2) thinks that the listening selection depends on the purpose of listening task. On the basis of listening purpose, interactional and transactional listening can be referred as well. Vandergrift (2002:2) has explained the matter as:

Interactional use of language is socially oriented, existing largely to satisfy the social needs of the participants; e.g., small talk, and casual conversations. Therefore, interactional listening is highly contextualized and twoway, involving interaction with a teacher. A Transactional use of language, on the other hand, is more messageoriented and is used primarily to communicate information; e.g., news broadcasts and lectures. In contrast with interactional listening, transactional listening requires accurate comprehension of a message with no opportunity for clarification with a speaker (one-way listening)

\section{The study method}

\subsection{Participants}

For the questionnaire survey, three hundred students from 10 private universities and twenty six teachers have been selected at random from 11 private universities. The universities surveyed are, BRAC University, East West University, Eastern University, Stamford University, State University of
Bangladesh, The People's University of Bangladesh, University of Development Alternative, Dhaka International University, Asian University, Independent University of Bangladesh and Northern University.

\subsection{Survey instruments}

To collect information, questionnaires were developed both for the students and the teachers. The questionnaire for the students consisted of six multiple choice questions whereas, the questionnaire for the teachers consisted of six multiple choice questions along with an open ended question. In the openended question the teachers were given the scope to incorporate their valuable suggestions in the questionnaire. Both the questionnaires were prepared in such a way that could help a comparative study. For data analysis, a common statistical tool like descriptive statistics was used.

\subsection{Analysis of Students' Information}

After collecting and analyzing the data, it has been found that most of the students (225 students, $75 \%$ ) answered that the medium of instruction at their university is mixture of English and Bangla whereas $25 \%$ students (75 students) replied that the medium of instruction is solely English. Second question was set to know the student's capability of understanding the English lectures given by their teachers. Hence, we have found that $60.33 \%$ students answered that they understand the English lectures and other $39.33 \%$ students replied that they sometimes understand and sometimes struggle for that (in Table 1.1). The third question was set to know the reasons for not being able to properly understand the English lectures. We have found that $34.33 \%$ students answered that, for difficult content they face problem. Another $21 \%$ students replied that they face problem for not understanding the pronunciation of the teachers. The rest $15 \%$ students recognized poor listening skill for not understanding the English lectures delivered by the teachers; and the other $29.66 \%$ students referred all reasons in Vol. 2 No. 3 February, 2009 
the questionnaire for their poor understanding of English lectures. The fourth question was set to know the capability of students' understanding of native English. We have found that $64 \%$ students sometimes can understand native English and other $36 \%$ students can fully understand.

Table 1.1

Data collected from students

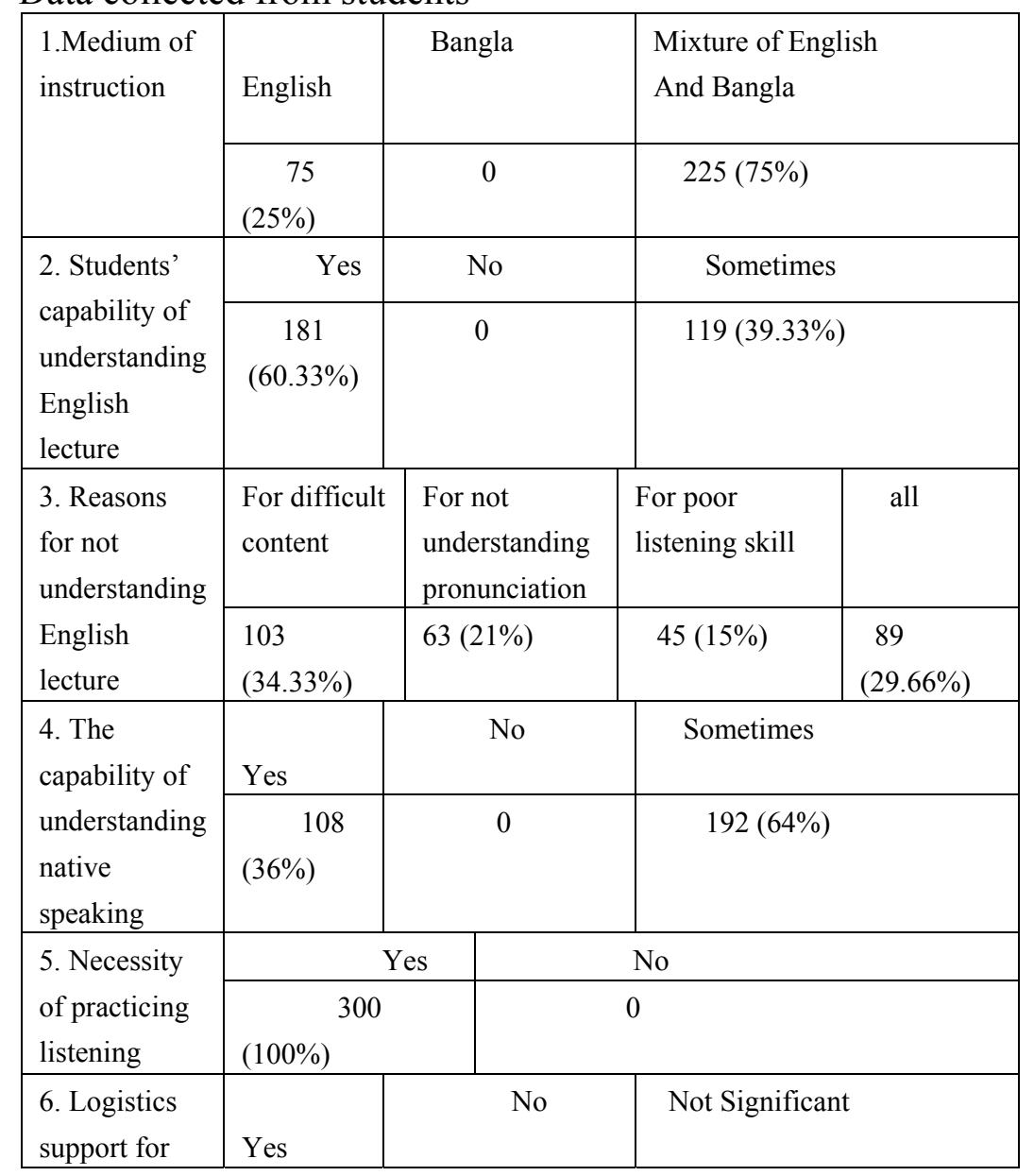

The Dhaka University Journal of Linguistics

\begin{tabular}{|l|r|r|l|}
\hline $\begin{array}{l}\text { listening } \\
\text { practice }\end{array}$ & $\begin{array}{r}32 \\
(10.66 \%)\end{array}$ & $\begin{array}{c}118 \\
(39.33 \%)\end{array}$ & $150(50 \%)$ \\
\hline
\end{tabular}

The fifth question was set to know the necessity of practicing listening; and surprisingly it has been found that $100 \%$ students felt the necessity of practicing listening skill to the fullest extent. The last question was set to know in terms of having logistic support for practicing listening. It has been found that $50 \%$ students replied that their logistic support is not adequate; amazingly it has been found that $39.33 \%$ students said that they had not any logistic support for practicing listening; whereas $32 \%$ students were satisfied with logistic support they have at their disposal.

\subsection{Analysis of Student's Information}

When we have analyzed the data collected from the English teachers, from the first question we have found the information that all the teachers (26) think that all the skills should be given equal importance. From the question no. 2 we have found that $61.53 \%$ teachers deliver their lectures using both English and Bangla language whereas $38.46 \%$ teachers deliver their lectures thoroughly in English. From question no. 3, it has been found that $46.15 \%$ teachers believe that most of the time students understand their lecture whereas $38.46 \%$ teachers claim that students request for Bangla explanation; and only 15.38 teachers believe that their students always understand their lecture. The fourth question was set to know whether the option of listening skill development is incorporated in the syllabus or curriculum of their universities. It has been found that $61.53 \%$ teachers replied that the option is not directly included in the syllabus; whereas $26.92 \%$ teachers said that their syllabuses include option for listening development; and $11.53 \%$ teachers claimed that there is no option for listening development in their syllabus.

Vol. 2 No.3 February, 2009 
Table 1.2

Data collected from teachers

\begin{tabular}{|c|c|c|c|}
\hline \multirow{2}{*}{$\begin{array}{l}\text { 1. Four skills } \\
\text { should be given } \\
\text { equal importance }\end{array}$} & \multicolumn{2}{|c|}{ Yes } & No \\
\hline & \multicolumn{2}{|c|}{$100 \%$} & 0 \\
\hline \multirow[t]{2}{*}{$\begin{array}{l}\text { 2. The way of } \\
\text { delivering lecture }\end{array}$} & $\begin{array}{l}\text { Thorough } \\
\text { English }\end{array}$ & $\begin{array}{l}\text { English } \\
\text { (Using } \\
\text { Bangla } \\
\text { explanation) }\end{array}$ & $\begin{array}{l}\text { Mostly in } \\
\text { Bangla }\end{array}$ \\
\hline & $\begin{array}{c}10 \\
(38.46 \%) \\
\end{array}$ & $\begin{array}{r}16 \\
(61.53 \%) \\
\end{array}$ & 0 \\
\hline \multirow[t]{2}{*}{$\begin{array}{l}\text { 3. Students' } \\
\text { understanding of } \\
\text { the lecture }\end{array}$} & Yes & $\begin{array}{l}\text { Most of the } \\
\text { time they } \\
\text { understand }\end{array}$ & $\begin{array}{l}\text { Request for } \\
\text { Bangoli } \\
\text { Explanation }\end{array}$ \\
\hline & $\begin{array}{c}4 \\
(15.38 \%)\end{array}$ & $\begin{array}{c}12 \\
(46.15 \%)\end{array}$ & $\begin{array}{c}10 \\
(38.46 \%)\end{array}$ \\
\hline \multirow{2}{*}{$\begin{array}{l}\text { 4. Option for } \\
\text { development of } \\
\text { listening skill in } \\
\text { syllabus/curriculu } \\
\mathrm{m}\end{array}$} & Yes & No & $\begin{array}{c}\text { Nor } \\
\text { Directly }\end{array}$ \\
\hline & $\begin{array}{c}7 \\
(26.92 \%)\end{array}$ & $\begin{array}{c}3 \\
(11.53 \%)\end{array}$ & $\begin{array}{c}16 \\
(61.53 \%)\end{array}$ \\
\hline \multirow{2}{*}{$\begin{array}{l}\text { 5. Logistic } \\
\text { support for } \\
\text { teaching listening }\end{array}$} & Yes & No & $\begin{array}{r}\text { Not } \\
\text { enough }\end{array}$ \\
\hline & $\begin{array}{c}9 \\
(34.61 \%)\end{array}$ & $\begin{array}{c}3 \\
(11.53 \%)\end{array}$ & $\begin{array}{c}14 \\
(53.84 \%)\end{array}$ \\
\hline \multirow[t]{2}{*}{$\begin{array}{l}\text { 6. should take } \\
\text { special care for } \\
\text { listening skill }\end{array}$} & Yes & No & $\begin{array}{l}\text { Will grow } \\
\text { automatical } \\
\text { ly }\end{array}$ \\
\hline & $\begin{array}{c}25 \\
(96.15 \%)\end{array}$ & 0 & $\begin{array}{c}1 \\
(3.84 \%)\end{array}$ \\
\hline
\end{tabular}

The fifth question was set to know whether the teachers have enough logistic support for teaching listening. 34.61\% teachers said that they had enough logistic support for teaching

The Dhaka University Journal of Linguistics listening; whereas $11.53 \%$ teachers replied that they did not have enough logistic support; again $53.84 \%$ teachers said that they had logistic support for teaching listening but the support is not enough. The sixth question was set to know whether the teachers should take special care regarding the development of students' listening skill. It is not surprising that $96.15 \%$ teachers said that they should take special care in this respect; whereas only $3.84 \%$ teachers believe that listening skill will be developed automatically.

\section{Discussion of the Findings}

The purpose of this study was to focus on the real scenario of listening skill at tertiary level in Bangladesh. It has been an effort to find out the reasons that are active behind students' poor listening skill. It has been observed that students carry out the poor listening skill from their primary and intermediate level to tertiary level and listening skill is not emphasized at any of these levels. So, it remains unattended through out their academic life. As listening skill of English remains unattended in all phases of the students' educational journey, students loose interest in listening and gradually become poor listener. It has also been identified that sometimes even language teachers do not give attention to listening skill and most of the times other skills are given priority over listening skill. So, students do not feel any urge to improve their listening skill like other language skills.

However, it has also been revealed that most of the students do not feel comfortable with constant English lecture given by their teachers rather they prefer lectures in a combined language (mixture of English and Bangla) which they think is easier to comprehend. It has also been identified that students sometimes struggle to understand the lectures given by their teachers. They have also identified different reasons for not understanding English lectures; among them the most common reason is difficult content and other reasons are pronunciation Vol. 2 No. 3 February, 2009 
of the teachers and poor listening skill of the learners. The last two reasons are directly with listening skill of the learners. Interestingly, a good number of students have identified all of the reasons responsible for their inability to understand the lectures in English. A potential number of students have agreed that sometimes they struggle to understand the native English pronunciation and it definitely indicates students' uneasiness with English listening skill. Students are very much aware of their lacking and feel the importance of improving the listening skill. So, we find cent percent students have given their opinion in support of practicing listening. At the end, we have found that half of the surveyed students have acknowledged that they do not have enough logistics support for the development of listening skill. A very few number of students claim that they enjoy facilities for the development of their listening skill.

Next, we can consider the responses that we have received from different language teachers. All of them agreed that no skills should be left unattended and all four skills should be given equal importance. In addition to that, it has been found that most of the language teachers give their lectures in English but for better understanding of the learners they also provide Bangla explanation. Again, we have found that very few teachers think that students understand thorough English lecture and a good number of teachers have mentioned that students request for Bangla explanation. Besides, it has been found that most of the teachers believe that in the syllabus and in the curriculum the option for developing listening skill is not included directly; whereas some teachers have given their opinion that this is included in syllabus/curriculum. It is not surprising that most of the teachers have referred to an inadequate logistic support for teaching listening, but it has also been found that few teachers have claimed that they have enough logistic support for teaching listening (though they are very few in numbers). At the last but not the least, almost all of

The Dhaka University Journal of Linguistics the language teachers have agreed that extra care should be taken for the improvement of listening skill of the learners. After analyzing all the suggestions given by the teachers, we can say that still there is immense scope for the development of listening skill of the learners. Both the teachers and learners should come forward to materialize the suggestions in this regard.

\section{Conclusion and Recommendations}

From the above findings and discussions, it can be claimed that as listening skill is neglected in our country from the very beginning of learners' educational life, EFL (English as a foreign language) teachers should give priority in teaching listening. As no skill should be taught in isolation, teachers can incorporate teaching listening with the other skills, thus the learners will be benefited ultimately. In brief, in Bangladeshi context, we suggest the following suggestions:

1. Motivation is very important in case of teaching listening. Our teachers can come forward with positive motivation to drive away the anxiety about the listening skill. In teaching listening, teachers should give maximum importance to the listening process and he/she shouldn't be too much rigid about the evaluation of the learners. Using listening activities for testing only leads to anxiety, which weaken the development of meta cognitive strategies.

2. Teachers should help students to grow prior knowledge regarding the listening materials, so that learners will be able to connect their background knowledge with the listening materials. Otherwise if the learners find both context and content entirely unknown to them they will lose interest. As a result, the development of listening skill of the learners will be stuck.

3. Listening purpose should be determined beforehand both by the teachers and the learners in order to get maximum benefits

$$
\text { Vol. } 2 \text { No.3 February, } 2009
$$


from the listening materials. The selection of listening materials completely depends on the purpose of listening whether it is for extensive listening or intensive.

4. Our Learners hardly get any exposure to listening materials (authentic or prepared). Tape recorder is the most fruitful kind of listening material in practicing listening. In classroom activities while listening will be practiced, students should be given more than one chance for hearing the same materials. Initially it might create problem but after some days of practice, hopefully students will need less repetition.

5. Students should be taught to handle the listening materials with their own hand. By this kind of practice students' confidence level will be heightened.

6. Teachers should encourage the students to build up rich vocabulary stock. Teachers should also motivate them to improve their critical listening skill.

7. Listening is all about practice. The more exposure the learners will get the more they will be competent. It is not necessary that students will practice listening in class room only. For the development of Extensive listening they can be encouraged to watch English movies with sub-title, listen to English song, documentary show English news, sports commentary etc.

8. Most of the students are now equipped with mobile phone and it is a common practice of listening FM radio for entertainment. Students can be encouraged to hear BBC (FM broadcast) in their mobile phone. The government can take initiative to start education based FM radio channel in English.

9. The scope of development of listening skill must be incorporated in the UGC prescribed syllabus.

We know that there is huge obstacles in practicing listening in secondary, higher secondary even at the tertiary level. Most of

The Dhaka University Journal of Linguistics our private universities are not well equipped in this respect. More over, listening skill is not directly included in the syllabus/ curriculum in most of the private universities. In light of the suggestions given above if proper steps are taken, the weakness of the learners in listening skill will no longer last in our country.

\section{References}

Byrnes, H. 1984. The Role of Listening Comprehension: A Theoretical Base. Foreign Language Annals, 17: 317-29.

Chomsky, N. 1965. Aspects of the Theory of Syntax. Cabridge: MIT Press.

Harmer,J. 1998. how to Teach English. Edinburgh: Addison Wesley Longman limited.

Harmer,J. 2001. The Practice of English Language Teaching. Edinburgh: Person Education Limited.

Hymes, D.1972. On communicative competence. In J.B.Pride and J. Holmes (eds.), Sociolinguistics. Harmondsworth: Penguin. 269-293.

Jahan, A. and Jahan,N. (2008). Taching Presentation Skills to Tertiary Students in Bangladesh. Stamford Journal of English, 4: 38-57.

Johnson, J. 1994. The National Oracy Project. In Brindley, S. (ed), Teaching English, 31-42. New York: Routledge.

Perera, K. 1994. Standard English The Debatae. In Brindley, S. (ed), Teaching English, 79-88. New York: Routledge.

Richards, J.C. 1990. The Language Teaching Matrix. New York: Cambridge University Press.

Richards, J.C. and Rodgers, T.S. 2001. Approaches and Methods in Language Teaching. New York: Cambridge University Press.

Rixon,S. 1986 . Development Listening Skills. London: Shelagh Rixon Publication.

Tomlison, B. (1998). Materials Development. Cambridge: Cambridge University Press.

Vol. 2 No.3 February, 2009 
Vandergrift,L. Linguistic: theory and practice in modern foreign language competence. Retrieved on 13 May,2009, from http://www.llas.ac.uk/resources/gpg/67

Wift,J. (1984). Strategies for Teaching School Language Listening Comprehension. Foreign Language Annals, 17: 345-48.

\section{Appendix 1}

\section{A survey on the development of listening skill of the learners at tertiary level.}

\section{For Teachers}

\section{[Please give tick $(\sqrt{ })$ mark on the suitable option]}

1. Do you think that the four skills (reading, writing, speaking $\&$ listening) of English language should be given equal importance?
a. Yes;
b. No.

2. How do you deliver your lecture?

a. In thorough English

b. In English using Bengoli explanation (for students' better understanding)

c. Mostly in Bengoli

3. Do your students understand the English lecture delivered by you?
a. Yes
b. Most of the time
c. Students request for Bengoli explanation

4. In the syllabus/ curriculum is there any option for the development of the listening skill of the students?
a. Yes
b. No
c. Not directly

5. If in the syllabus/ curriculum there is the option of developing listening skill, is there enough logistic support for teaching that?
a. Yes
b. No
c. Not enough

5. As an English teacher, do you think the teachers should take special care about the development of the listening skill of the students along with other skills?
a. Yes
b. No
c. Listening skill will be
developed automatically

7. Do you have any suggestion regarding the development of the listening skill of the students? Please mention it.

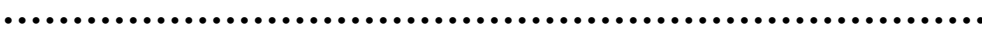



\section{Teacher's information:}

(The information collected will be kept confidential)

Name

Date

Name of the educational institution :

\section{Designation}

Mo. No (if any) :

\section{E-mail ID}

The Dhaka University Journal of Linguistics 


\section{Appendix 2}

\section{A survey on the development of listening skills of the learners at tertiary level}

\section{For the Students}

\section{[Please give tick $(\sqrt{ })$ mark on the suitable option]}

1. What is the medium of instruction at your college/ university?
a. English
b. Bengoli
c. Mixture of English \&
Bengoli

2. Do you understand the English Lecture delivered by your teachers?
a. Yes
b. No
c. Sometimes

3. If you do not understand the English lecture delivered by your teacher, then point out the reason from the followings:

a. for difficult content ( for difficult subject matter)

b. for not understanding the pronunciation

c. for poor listening skill

d. all

4. Do you understand the English speaking of the native speaker? (Dialogue from Movie, native English conversation, $\mathrm{BBC}$ or $\mathrm{CNN}$ news etc)
a. Yes
b. No
c. Sometimes

5. Do you think you should practice or you should take special care about your Listening skill?

a. Yes b. No
6 Is there enough logistic support for the students to practice listening?
a. Yes
b. No
c. Not significant

\section{Student's information:}

(The information collected will be kept confidential)

Name

Date

Name of the educational institution :

Level of study (year/ semester/ batch) :

Mo. No (if any) :

E-mail ID

Email Address : minhaj.abedin@gmail.com 